\title{
Malignant Extraskeletal Cartilaginous and Osseous Neoplasm
}

National Cancer Institute

\section{Source}

National Cancer Institute. Malignant Extraskeletal Cartilaginous and Osseous Neoplasm. NCl Thesaurus. Code C6572.

A malignant mesenchymal neoplasm with cartilaginous or osseous differentiation arising from the soft tissues exclusively. Extraskeletal osteosarcoma is a representative example. 